\author{
S.F. Pylypaka ${ }^{1}$, M.B. Klendii ${ }^{2}$, V.I. Trokhaniak ${ }^{1}$, A.S. Pastushenko ${ }^{3}$, A.V. Novitskiy ${ }^{1}$ \\ ${ }^{1}$ National University of Life and Environmental Sciences of Ukraine, Kyiv, Ukraine; \\ ${ }^{2}$ Separated Subdivision of National University of Life and Environmental Sciences of Ukraine \\ Berezhany Agrotechnical Institute, Ukraine; \\ ${ }^{3}$ Mykolayiv National Agrarian University, Ukraine \\ (E-mail: trohaniak.v@gmail.com)
}

\title{
Movement of a material particle on an inclined plane all the points of which describe circles in oscillatory motion in the same plane
}

\begin{abstract}
Differential equations of material particle movement on an inclined rough plane, which performs oscillatory motion in such a way that its every point describes a circle in the same plane, have been deduced. Peculiarities of relative particle movement on a plane depending on the angle of its inclination to the horizon have been investigated. The equations have been solved using numerical methods. Relative velocities have been found and particle motion trajectories have been constructed. Kinematic characteristics of relative particle movement depending on the angle of plane inclination, angular velocity, the coefficient of particle friction on a plane and the radius of circular motion of plane points have been determined.
\end{abstract}

Keywords: inclined plane, oscillatory motion, relative motion, particle, kinematic parameters.

\section{Introduction}

An inclined plane is a general purpose construction element of numerous agricultural machines [1]. In the course of processing technological material moves on it. Particle movement on a horizontal plane that performs oscillatory straight-line or circulatory motion is the best investigated. As for an inclined plane, investigations are mainly conducted for its rectilinear reciprocating horizontal oscillations in the direction of plane inclination or in the transverse direction [1]. If there are non-rectilinear plane oscillations, when all its points describe a circle and the plane itself is inclined, the movement of technological material changes significantly.

In addition to the fundamental monograph [1] that covers rectilinear reciprocating oscillations, there are works focused on non-rectilinear plane oscillations. Academician P.M. Zaika [2] investigated the movement of a spherical particle on a horizontal plane, which performs translational oscillations in a circle and other [3, 7]. In fact, the problem of material particle movement on a plane that performs circular oscillatory motion was first solved in geometric interpretation [8], generalized and applied to the cases of elliptical vibrations by I.I. Blekhman [9]. Investigations of material particle movement on a rough horizontal plane, that performs horizontal translational oscillations on various curves, are covered in the papers [10-19].

\section{Material and research methods}

Let us locate a plane in such a way that it is inclined to the horizon at an angle $\beta$ (Fig. 1). A particle performs relative movement on an inclined plane, where there are plane coordinates ouv arranged in such a way that ou axis in directed in the line of the greatest inclination. The inclined plane together with plane coordinates perform oscillations in such a way that all the points of the plane describe circles of radius $R$ in the same plane (Fig. 1,a, these circles are presented only in the apexes of the rectangle, which limits the plane). Absolute particle motion is considered relative to the fixed coordinate system $O x y z$, where $O y$ axis coincides with $o v$ axis, and there is the angle $\beta$ between the inclined plane ouv and the coordinate horizontal plane $O x y$. The origin of the moving coordinate system (point $o$ ) describes a circle as well. Fig. 1 presents the two systems at the time when their coordinate origins coincide.

In order to develop differential equations of particle movement, it is necessary to use its absolute trajectory in the fixed coordinates Oxyz. The absolute trajectory of a particle is written as the sum of the corresponding components in the translational motion and in the relative motion:

$$
x=x_{t}+x_{r} ; \quad y=y_{t}+y_{r} ; \quad z=z_{t}+z_{r},
$$

where $x_{t}=x_{t}(t) ; y_{t}=y_{t}(t) ; z_{t}=z_{t}(t)$ is a trajectory of translational motion as a function of time;

$x_{r}=x_{r}(t) ; y_{r}=y_{r}(t) ; z_{r}=z_{r}(t)$ is a trajectory of relative motion as a fuction of time. 


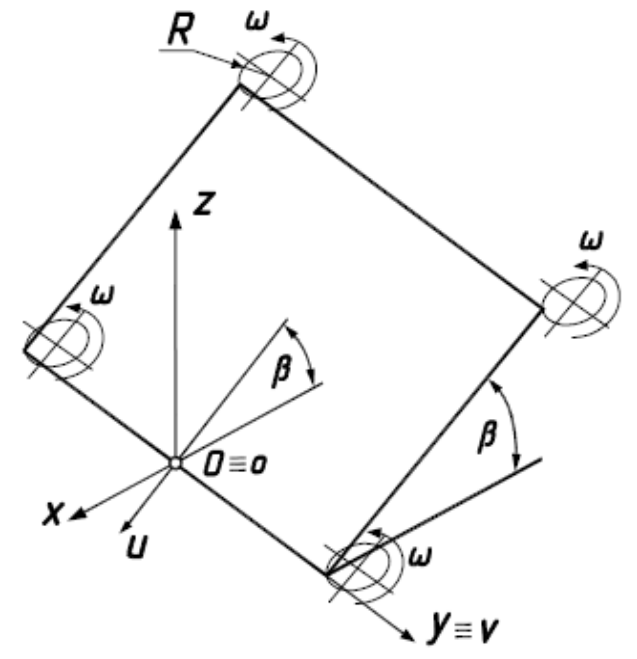

a

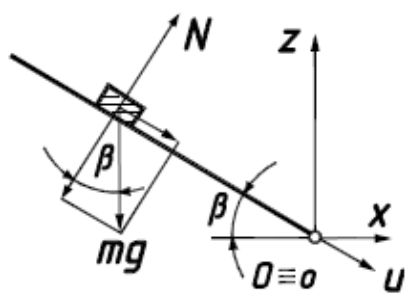

b

Figure 1. Consideration of particle movement on an inclined plane with all its points describing circles at oscillations in the same plane: a) mutual arrangement of the moving coordinate system ouv and the fixed coordinate system $O x y z$ at the initial moment, when their coordinate origins coincide; b) particle position on a plane, when it is projected into a line

Every point of an inclined plane, including the origin of the moving coordinate system ouv, describes a circle of radius $R$. In the projections on the axes of the fixed coordinate system, relative motion of a plane is presented by the following parametric equations:

$$
x_{t}=R \cos \beta \cos \omega t ; \quad y_{t}=R \sin \omega t ; \quad z_{t}=-R \sin \beta \cos \omega t,
$$

where $\omega$ is angular velocity of rotation of every point of a plane.

A particle slides on an inclined plane and its sliding trajectory in the moving coordinate system ouv is written as a function of time $t: u=u(t) ; v=v(t)$. In the projections on the axes of the fixed coordinate system, relative particle movement is described by the following parametric equations:

$$
x_{r}=u \cos \beta ; \quad y_{r}=v ; \quad z_{r}=-u \sin \beta .
$$

By summing translational and relative motion applying the formula (1), we obtain:

$$
x=R \cos \beta \cos \omega t+u \cos \beta ; \quad y=R \sin \omega t+v ; \quad z=-R \sin \beta \cos \omega t-u \sin \beta .
$$

The dependences $u=u(t) ; v=v(t)$, that describe the trajectory of relative motion (particle sliding on an inclined plane), are the unknown functions that must be determined. By differentiating the equations (4) with respect to the time $t$, the projections of absolute particle velocity on the fixed coordinate system Oxyz are obtained:

$$
\begin{aligned}
& x^{\prime}=-R \omega \cos \beta \sin \omega t+u^{\prime} \cos \beta ; \\
& y^{\prime}=R \omega \cos \omega t+v^{\prime} ; \\
& z^{\prime}=R \omega \sin \omega t-u \sin \beta .
\end{aligned}
$$

Differentiation of the expressions (5) allows for projecting absolute acceleration:

$$
\begin{aligned}
& x^{\prime \prime}=-R \omega^{2} \cos \beta \cos \omega t+u^{\prime \prime} \cos \beta ; \\
& y^{\prime \prime}=-R \omega^{2} \sin \omega t+v^{\prime \prime} ; \\
& z^{\prime \prime}=R \omega^{2} \sin \beta \cos \omega t-u^{\prime \prime} \sin \beta .
\end{aligned}
$$

Let us deduce a motion equation in the form of $m \bar{w}=\bar{F}$, where $m$ is particle mass, $\bar{w}$ is absolute acceleration vector, $\bar{F}$ is the resultant vector of the forces applied to a particle. Such forces include weight force $m g\left(g=9,81 \mathrm{~m} / \mathrm{s}^{2}\right)$, the response $N$ of an inclined plane and friction force $f N$ at particle sliding on a plane ( $f$ is friction coefficient). All the forces must be projected onto the axes of the fixed coordinate system.

Weight force is directed downwards, thus, its projections are written as:

$$
\{0 ; \quad 0 ; \quad-m g\} \text {. }
$$


The response $N$ of a plane is perpendicular to it (Fig. 1,b) and has the following projections:

$$
\{N \sin \beta ; \quad 0 ; \quad N \cos \beta\} .
$$

Since friction force is directed at a tangent to the trajectory of relative particle motion in the opposite direction, let us find the projections of the tangent vector. They are determined by the first derivatives of the equations (3):

$$
x_{r}=u^{\prime} \cos \beta ; \quad y_{r}=v^{\prime} ; \quad z_{r}=-u^{\prime} \sin \beta .
$$

The geometric sum of the components (7) provides the velocity of particle sliding on the surface of a cylinder in relative motion:

$$
V_{r}=\sqrt{x_{r}^{\prime 2}+y_{r}^{\prime 2}+z_{r}^{\prime 2}}=\sqrt{u^{\prime 2}+v^{\prime 2}} .
$$

The unit tangent vector in the projections on the axes of the moving coordinate system Oxyz is obtained from dividing the projections $(7)$ by the vector value (8):

$$
\left\{\frac{u^{\prime} \cos \beta}{\sqrt{u^{\prime 2}+v^{\prime 2}}} ; \quad \frac{v^{\prime}}{\sqrt{u^{\prime 2}+v^{\prime 2}}} ; \quad-\frac{u^{\prime} \sin \beta}{\sqrt{u^{\prime 2}+v^{\prime 2}}}\right\} .
$$

Let us break down the vector equation $m \bar{w}=\bar{F}$ in the projections on the axes of the fixed coordinate system, taking into account that the friction force $f N$ is directed along the unit vector (9) oppositely to it:

$$
\begin{aligned}
& m x^{\prime \prime}=N \sin \beta-f N \frac{u^{\prime} \cos \beta}{\sqrt{u^{\prime 2}+v^{\prime 2}}} ; \\
& m y^{\prime \prime}=-f N \frac{v^{\prime}}{\sqrt{u^{\prime 2}+v^{\prime 2}}} ; \\
& m z^{\prime \prime}=-m g+N \cos \beta+f N \frac{u^{\prime} \sin \beta}{\sqrt{u^{\prime 2}+v^{\prime 2}}} .
\end{aligned}
$$

Let us insert other derivatives (projections of absolute acceleration) from (6) into the equation (10) and we obtain the system of three equations:

$$
\begin{aligned}
& m\left(-R \omega^{2} \cos \beta \cos \omega t+u^{\prime \prime} \cos \beta\right)=N \sin \beta-f N \frac{u^{\prime} \cos \beta}{\sqrt{u^{\prime 2}+v^{\prime 2}}} ; \\
& m\left(-R \omega^{2} \sin \omega t+v^{\prime \prime}\right)=-f N \frac{v^{\prime}}{\sqrt{u^{\prime 2}+v^{\prime 2}}} ; \\
& m\left(R \omega^{2} \sin \beta \cos \omega t-u^{\prime \prime} \sin \beta\right)=-m g+N \cos \beta+f N \frac{u^{\prime} \sin \beta}{\sqrt{u^{\prime 2}+v^{\prime 2}}} .
\end{aligned}
$$

The system (11) includes three unknown functions: $N=N(t), u=u(t)$ and $v=v(t)$. By solving it with respect to $N, u^{\prime \prime}$ and $v^{\prime \prime}$, we obtain a very simple expression for $N$ :

$$
N=m g \cos \beta \text {. }
$$

It follows from (12) that the force of $N$ surface pressure on a particle is a steady-state one. It is possible to obtain tentative verification that the mass $m$ in the equations reduces, if it is substituted in (12) and (10). After the rearrangement, the dependences $u^{\prime \prime}$ and $v^{\prime \prime}$ take the following forms:

$$
\begin{aligned}
& u^{\prime \prime}=R \omega^{2} \cos \omega t+g \sin \beta-f g \frac{u^{\prime} \cos \beta}{\sqrt{u^{\prime 2}+v^{\prime 2}}} \\
& v^{\prime \prime}=R \omega^{2} \sin \omega t-f g \frac{v^{\prime} \cos \beta}{\sqrt{u^{\prime 2}+v^{\prime 2}}} .
\end{aligned}
$$

The system (13) cannot be integrated in the analytical form. It must be solved using numerical methods. Analytical solution can be obtained for a special case when $f=0$, that is for an absolutely smooth plane:

$$
\begin{aligned}
& u=\frac{g t^{2}}{2} \sin \beta+c_{1} t-R \cos \omega t ; \\
& v=c_{2} t-R \sin \omega t,
\end{aligned}
$$

where $c_{1}, c_{2}$ is integration constants.

In order to find the absolute trajectory of a particle, it is necessary to insert the expressions (14) into the parametric equations (4):

$$
\begin{aligned}
& x=\frac{g t^{2}}{2} \sin \beta \cos \beta+c_{1} t \cos \beta ; \\
& y=c_{2} t ; \\
& z=-\frac{g t^{2}}{2} \sin ^{2} \beta-c_{1} t \sin \beta .
\end{aligned}
$$

The equations (15) describe a parabola that is located in an inclined plane. 
The research is conducted for a case, when $\beta=0$, that is to say, in the case of a horizontal plane, the absolute trajectory transforms into a straight line. This is predictable, since, if there is no friction, a particle does not response to plane oscillations moves in absolute motion as if it is fixed. The relative trajectory, which is the result of particle sliding on a plane, takes the correspondent curvilinear form near the absolute trajectory. If $\beta=0$ and $f \neq 0$, numerical integration of the equations (13) shows that the trajectory of particle relative motion is a circle. A particle slides in it after its motion is stabilized and it is possible to find the analytical solution of the differential equation system [10-12] for this case. The form of the relative trajectory during the transient period, that is after a particle gets onto a plane and up to its motion stabilization, depends on the reference conditions of integration: the value of velocity and its direction at the moment of getting onto a plane.

Let us consider that a particle falls vertically and meets the plane at a right angle. Let us assume that at the moment of meeting a plane its absolute velocity is equal to zero. Since a plane performs oscillatory motion at this moment, there is particle sliding on a plane. The value and the direction of sliding velocity (that is to say, the velocity of relative motion) is equal to the analogical values of the translation motion of a plane at the point of particle entering but the velocity is oppositely directed. The point of particle entering depends on the time $t_{0}$. Since every plane point describes a circle of radius $R$, a particle enters a certain point of this circle, which is determined by the radius vector angle of rotation about the angle $\varphi_{0}=\omega t_{0}$. Having inserted this value into the equation (2), it is possible to determine the point of particle entering a plane in the fixed coordinate system. The velocity value is determined by differentiating the equations (2). For example, $y_{t}^{\prime}=R \omega \cos \omega t=$ $=R \omega \cos \omega t_{0}=R \omega \cos \varphi_{0}$. Thus, $v^{\prime}\left(\varphi_{0}\right)=-y_{t}^{\prime}=-R \omega \cos \varphi_{0}$. Similarly, $u^{\prime}\left(\varphi_{0}\right)=-x_{t}^{\prime}=R \omega \sin \varphi_{0}$. These data are the reference conditions of integration. Fig. 2,a presents the trajectories of relative particle motion when it enters a plane after $45^{\circ}$ rotation of this plane around a circle in translational motion. Fig. 2,b presents the graph of change in sliding velocity, which is determined from the formula (8). Thus, the trajectory of relative particle motion after its motion is stabilized is a circle and, after this, the relative velocity becomes constant. The paper [7-9] provides the dependence of the circle radius $\rho_{r}$ is the trajectory of relative particle motion after its motion is stabilized - on $R, f$ and $\omega$ :

$$
\rho_{r}=R \sqrt{1-\left(\frac{f g}{R \omega^{2}}\right)^{2}}
$$
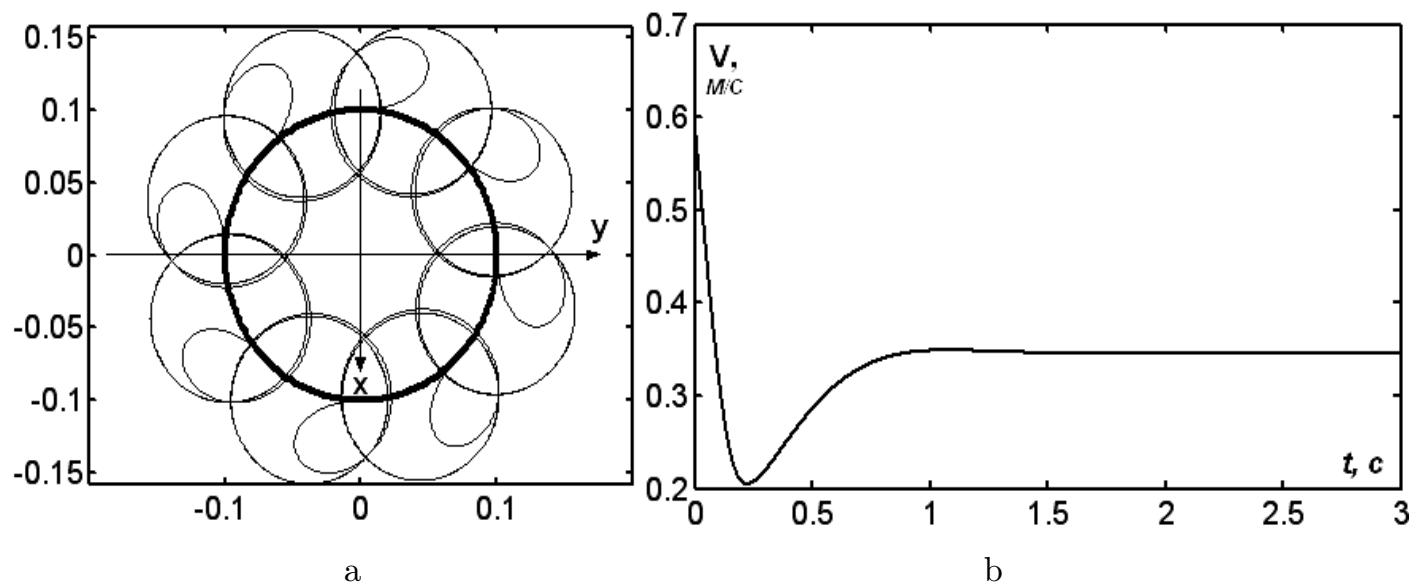

Figure 2. Kinematic characteristics of relative motion at $\omega=6 s^{-1}, R=0,1 \mathrm{~m}, f=0,3$ : a) relative trajectories originate from the circle of plane translational motion after $45^{0}$; b) graph of relative velocity $V_{r}$ change

The (16) shows that at the set values of $R$ and $f$, there is a critical value of the angular velocity $\omega$, at which relative motion is possible. If the angular velocity of plane oscillation is lower than the critical one, sliding is not possible: a particle «sticks» on a plane. If the angular velocity $\omega$ increases, the kinematic characteristics of a particle change: the radius $\rho_{\theta}$ of a circle of relative motion increases and reaches the one of a translational motion circle (Fig. 3,a) and the time of relative velocity stabilization increases (Fig. 3,b).

Let us determine the patterns of particle movement on an inclined plane that oscillates. The investigations show that, if there is a plane inclination beginning from the horizontal position, the trajectories of relative motion transform from circles into curves that are similar to cycloids (extended, regular, curtailed), here, their transformations take place with respect to the inclination of a plane in the order enumerated in the parentheses. 

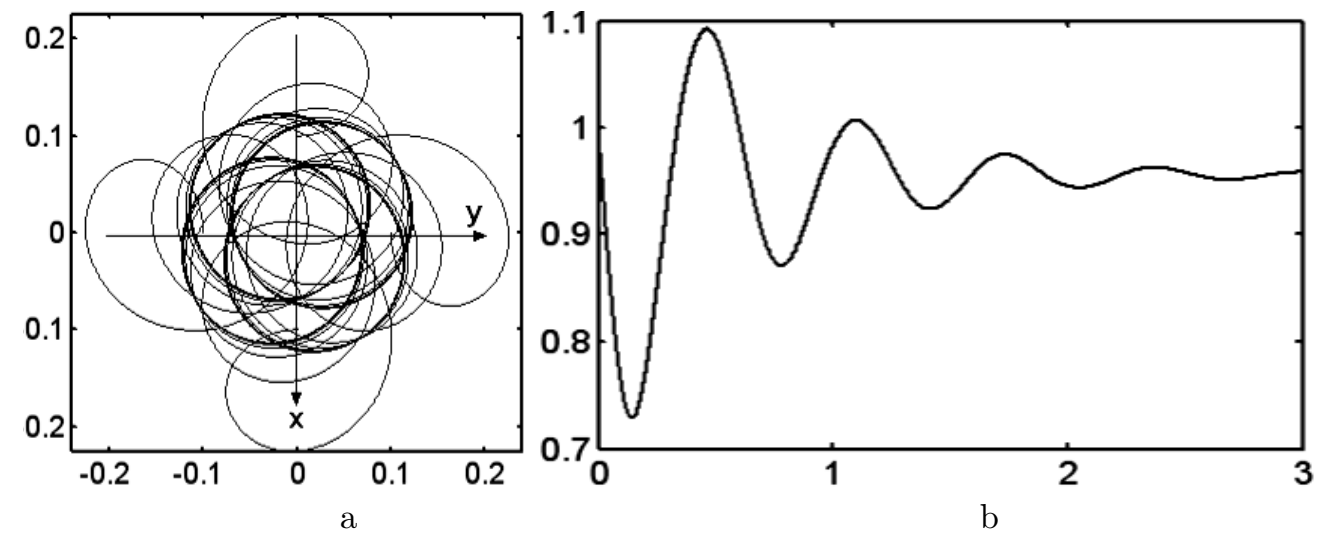

Figure 3. Kinematic characteristics of relative motion at $\omega=10 \mathrm{~s}^{-1}, R=0,1 \mathrm{~m}, f=0,3$ : a) relative trajectories originate from the circle of plane translational motion after $90^{\circ}$;

b) graph of relative velocity $V_{r}$ change

Fig. 4 presents the correspondent graphs of trajectories and velocities for $\omega=6 s^{-1}$ and $\omega=10 s^{-1}$ at the plane inclination being $\beta=2^{0}$. Similar to a horizontal plane, with the increase of the angular velocity $\omega$, the value of relative oscillations increases, here, their propagation direction does not coincide with the line of the greatest inclination, however, with the increase of the angular velocity it increasingly reaches it. As for the initial conditions, if there are high angles of plane inclination, it is necessary to take into account the velocity of particle motion in the vertical direction downwards at the moment of its entering a plane $\left(V_{0}\right)$. Relative sliding velocity is increased by the component $V_{0} \sin \beta$, that is $u^{\prime}\left(\varphi_{0}\right)=R \omega \sin \varphi_{0}-V_{0} \sin \beta$. This component plays its role only at the beginning of movement. Fig. 4 presents the graphs after motion stabilization. Particle relative velocity changes similar to a sinusoid, here, its maximum and minimum values remain constant. It is obvious that the oscillatory motion of a particle in the direction close to the line of the greatest inclination takes place uniformly, that is, the propagation velocity of sliding is constant. If the angle of plane inclination increases, for example, to $\beta=20^{\circ}$, the pattern of oscillations changes (Fig. 5). The trajectory becomes similar to a curtailed cycloid with a pitch that increases (Fig. 5,a) and relative velocity at the equal amplitude changes in such a way that its extremum values increase in linear fashion (Fig. 5,b). It means that oscillations have accelerated propagation.
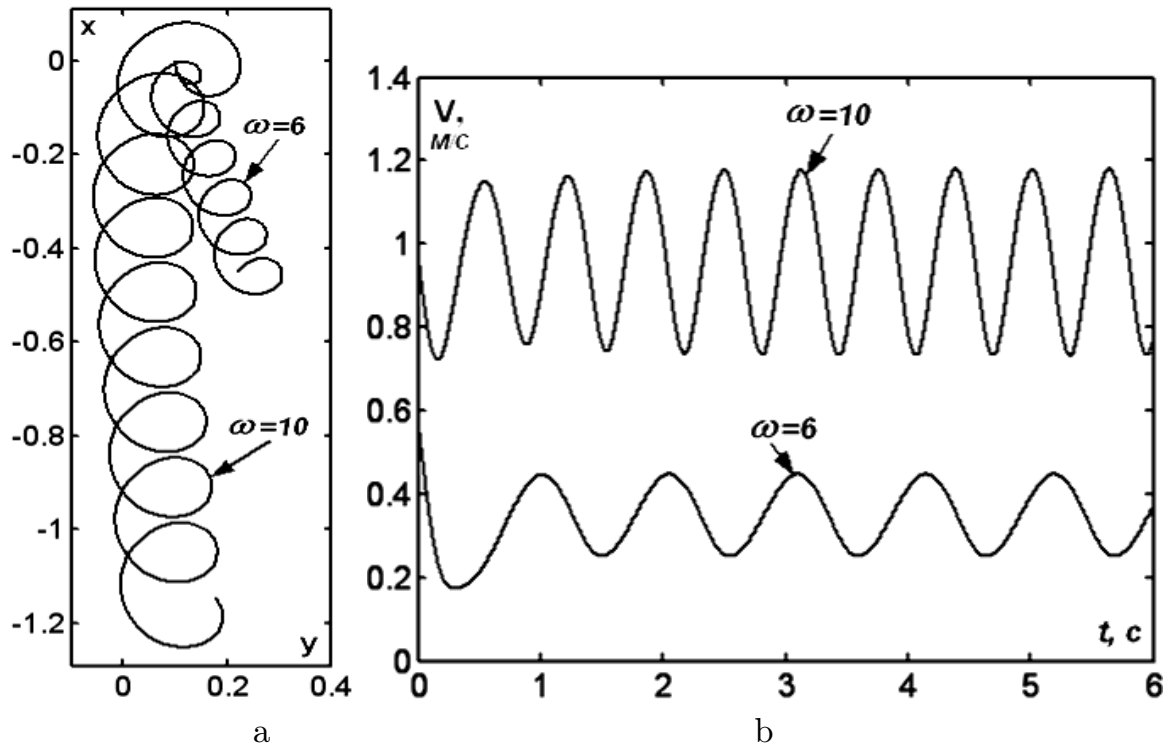

Figure 4. Kinematic characteristics of relative motion at

$$
\beta=2^{0}, R=0,1, f=0,3:
$$

a) relative trajectories; b) graphs of relative velocities

There is a question: at what value of the angle $\beta$ the pattern of propagation of oscillations transforms from the uniform to the accelerated one. It can be assumed that such a limit is the angle $\beta$, which is equal to a friction 
angle, that is $\beta=\operatorname{Arctg} f$ (at $f=0,3 \beta=16,7^{0}$ ). However, it is not the case, since at such an angle oscillations have accelerated propagation. It is obvious that the angle $\beta$ is smaller than the friction angle.

It was determined by trial and error method: $\beta=15,7^{0}$. In this case the trajectory is a curve, which is similar to a curtailed cycloid (Fig. 6,a). Relative velocity is stabilized in such a way that its value is changed within the limits of $1 \ldots 3 \mathrm{~m} / \mathrm{s}$ (Fig. 6,b). The investigations show that the limit between uniform particle oscillations and accelerated oscillations is the angle of plane inclination, which is somewhat smaller than the friction angle.

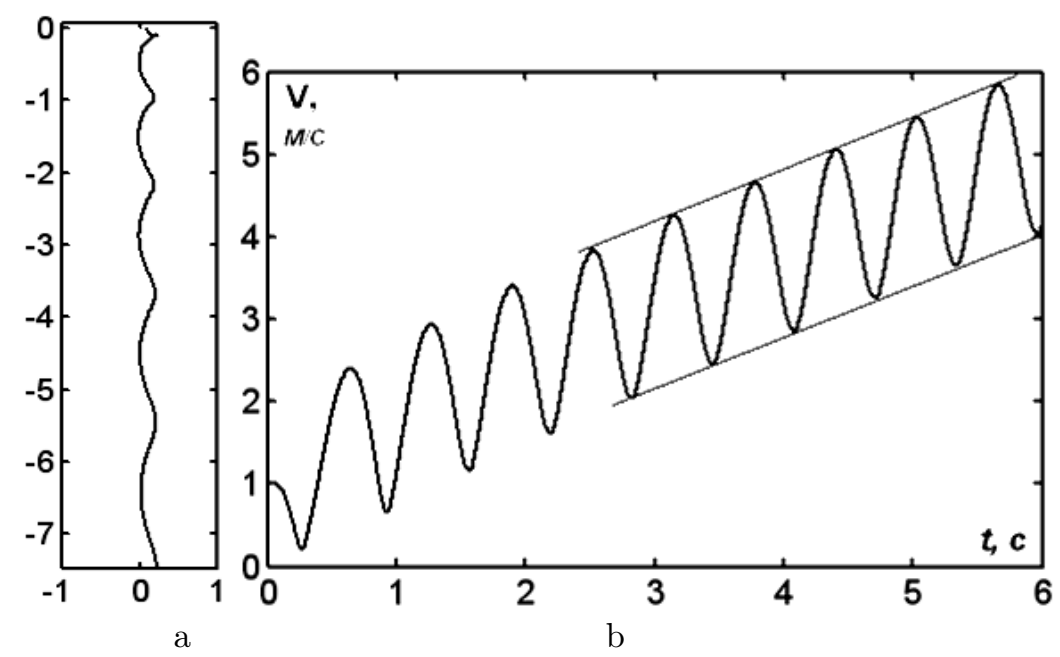

Figure 5. Kinematic characteristics of relative motion at $\beta=20^{0}, R=0,1, \omega=10 s^{-1}, f=0,3:$

a) relative trajectory; b) graph of relative velocity change

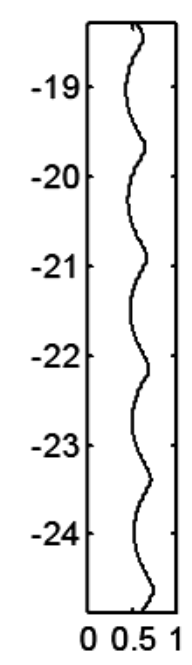

a

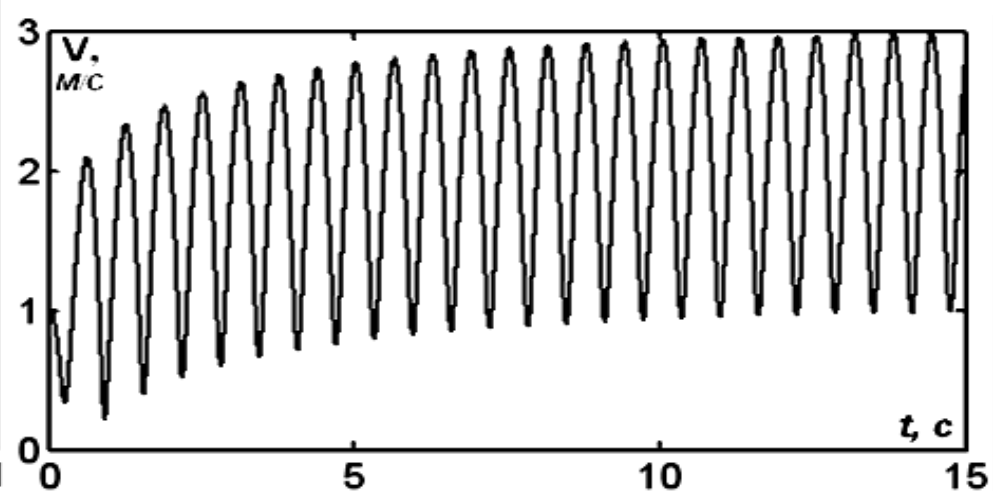

b

Figure 6. Kinematic characteristics of relative motion at $\beta=15,7^{0}, R=0,1, \omega=10 s^{-1}, f=0,3:$

a) relative trajectory; b) graph of relative velocity change

According to Fig. 4 and 6 , with the increase of the angle of plane inclination, the trajectory of a particle changes its form: it transforms from an extended cycloid into a curtailed one. It is logical to assume that at a certain intermediate angle $\beta$ it may be a regular cycloid. Such an intermediate angle was determined by trial and error method as well: $\beta=11^{0}$. The characteristic feature of such oscillations is the fact that a particle drastically changes is movement direction at the points of trajectory winding (Fig. 7,a), which is not possible without stopping. According to the graph of regular velocity change, its value ranges within the limits of $0 \ldots 2 \mathrm{~m} / \mathrm{s}$ (Fig. 7,b), that is, at the point of winding the velocity is equal to zero. 


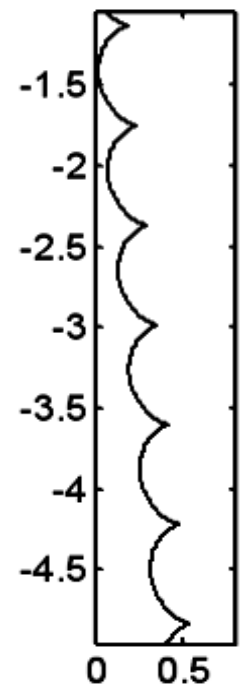

a

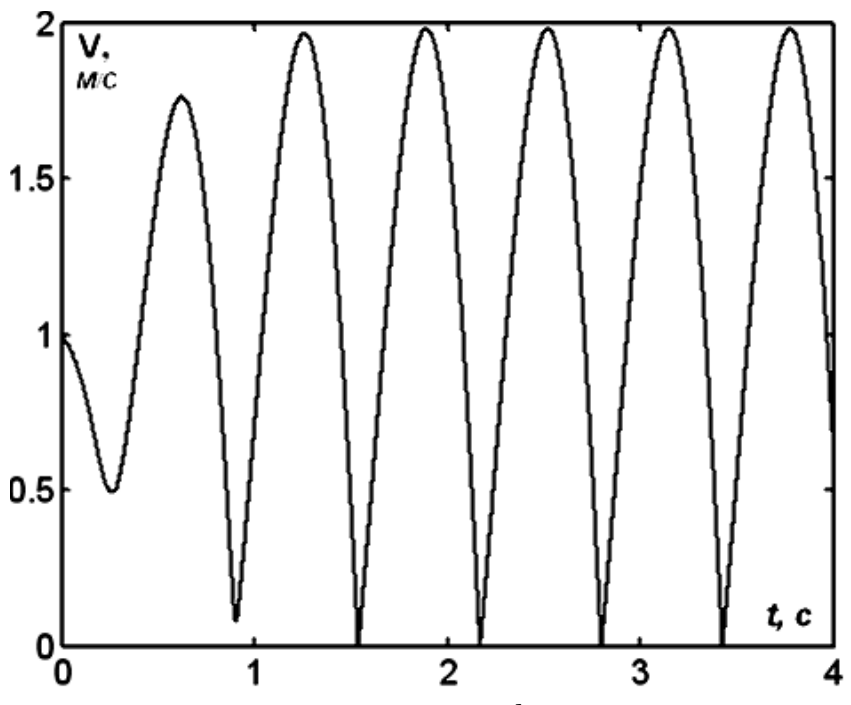

$\mathrm{b}$

Figure 7. Kinematic characteristics of relative motion at $\beta=11^{0}, R=0,1, \omega=10 s^{-1}, f=0,3:$

a) relative trajectory; b) graph of relative velocity change

\section{Conclusions}

The patterns of particle relative motion on a rough inclined plane, all the point of which describe circles in oscillatory motion in the same plane have been determined. At the inclination angle being $\beta=0^{0}$, that is, in the case of a horizontal plane, a particle describes a circle in relative motion, when the minimum angular velocity of plane oscillations is reached. If there is an increase of the angular velocity, a circle radius is the trajectory of relative motion is increases approaching to the radius of the circle of translational motion of plane oscillations. If the plane is inclined, beginning from a horizontal position, the trajectories of relative motion transform from circles into curves, which are similar to cycloids (extended, regular, curtailed), here, their transformations take place with respect to plane inclination in the order enumerated in the parentheses. With the increase of the angular velocity $\omega$, the pitch and the amplitude of relative particle oscillations increase, here, their propagation direction does not coincide with the line of the greatest inclination, however, with the increase of the angular velocity it approaches to it more and more. Until the moment when there is the boundary value of the inclination angle $\beta$ reached, which is somewhat smaller than the friction angle, oscillatory particle movement in the direction close to the line of the greatest inclination takes place uniformly, that is to say, the propagation velocity of oscillations in constant. Relative particle velocity changes similar to a sinusoidal law, here, its maximum and minimum values remain constant. If there is further increase of the inclination angle $\beta$, the trajectory pitch becomes changeable, that is to say, it increases and relative velocity changes at the same amplitude in such a way that its extremum values increase according to the linear law, that is to say, oscillations have accelerated propagation.

\section{References}

1 Василенко П.М. Теория движения частицы по шероховатым поверхностям сельскохозяйственных машин / П.М. Василенко. - Киев: УАСХН, 1960. - 283 с.

2 Заика П.М. Избранные задачи земледельческой механіки / П.М. Заика. - Киев: УСХА, 1992. $507 \mathrm{c.}$

3 Pylypaka S.F. Particle motion over the surface of a rotary vertical axis helicoid / S.F. Pylypaka, M.B. Klendii, O.M. Klendi // INMATEH: Agricultural Engineering. - 2017. - Vol. 51. - No. 1. P. $15-28$.

4 Pylypaka S. Particle motion over the surface of a cylinder, which performs translational oscillations in a vertical plane / S. Pylypaka, M. Klendii, T. Kremets, O. Klendii // Engineering Journal. - 2018. Vol. 22. - No. 3. - P. 83-92. 
5 Hevko R.B. Feasibility study of the process of transpotration and stirring of mixture in continuous-flow conveyers / R.B. Hevko, B.O. Yazlyuk, M.V. Liubin, O.A. Tokarchuk, O.M. Klendii, V.R. Pankiv // INMATEH: Agricultural engineering. - 2017. - Vol. 51. - No. 1. - P. 49-58.

6 Hevko R.B. Investigation of a transfer branch of a flexible screw conveyer / R.B. Hevko, M.B. Klendii, O.M. Klendii // INMATEH: Agricultural engineering. - 2016. - Vol. 48. - No. 1. - P. 29-34.

7 Hevko R.B. Development of design and investigation of operation processes of loading pipes of screw conveyors / R.B. Hevko, R.I. Rozum, O.M. Klendii // INMATEH: Agricultural engineering. - 2016. Vol. 50. - No. 3. - P. 89-96.

8 Пилипака С.Ф. Траєкторії руху частинок по шорсткій похилій площині при їх боковій подачі / С.Ф. Пилипака, А.В. Несвідомін. // Прикладна геометрія та інженерна графіка. — 2011. - № 87. C. $36-41$.

9 Блехман И.И. Вибрационное перемещение / И.И. Блехман, Г.Ю. Джанелидзе. - М.: Наука, 1964. $-410 \mathrm{c}$.

10 Pylypaka S. Particle motion on the surface of a concave soil-tilling disk / S. Pylypaka, M. Klendii, O. Klendii // Acta Polytechnica. - 2018. - Vol. 58. - No. 3. - P. 201-208.

11 Pylypaka S.F. Particle motion over the edge of an inclined plane that performs axial movement in a vertical limiting cylinder. / S.F. Pylypaka, M.B. Klendii, V.M. Nesvidomin, V.I. Trokhaniak // Acta Polytechnica. - 2019. - Vol. 59. - No. 1. - P. 67-76.

12 Pylypaka S. Particle motion over the surface of a cylinder, which performs translational oscillations in a vertical plane / S. Pylypaka, M. Klendii, T. Kremets, O. Klendii // Engineering Journal. - 2018. Vol. 22. - No. 3. - P. 83-92.

13 Pylypaka S.F. Conveyance of a particle by a vertical screw, which is limited by a coaxial fixed cylinder / S.F. Pylypaka, V.M. Nesvidomin, M.B. Klendii, I.L. Rogovskii, T.A. Kresan, V.I. Trokhaniak // Bulletin of the Karaganda University. «Mathematics» series. - 2019. - Vol. 95. - No. 3. - P. 67-77.

14 Hevko B.M. Improvement of machine safety devices / B.M. Hevko, R.B. Hevko, O.M. Klendi, M.V. Buriak, Y.V. Dzyadykevych, R.I. Rozum // Acta Polytechnica. - 2018. - Vol. 58. - No. 1. - P. 17-25.

15 Hevko R.B. Mathematical model of the pneumatic-screw conveyor screw mechanism operation / R.B. Hevko, V.O. Dzyura, R.M. Romanovsky // INMATEH: Agricultural engineering. - 2014. Vol. 44. - No. 3. - P. 103-110.

16 Klendii M.B. Interrelation between incidence angle and roll angle of concave disks of soil tillage implements / M.B. Klendii, O.M. Klendii // INMATEH: Agricultural engineering. - 2016. — Vol. 49. — No. 2. P. 13-20.

17 Romanovsky R.M. Justification of rational parameters of a pneumoconveyor screw feeder / R.M. Romanovsky, V.M. Baranovsky, R.B. Hevko, V.O. Dzyura, O.M. Klendii, M.B. Klendii // INMATEH: Agricultural Engineering. - 2018. - Vol. 54. - No. 1. - P. 15-24.

18 Hevko R.B. The influence of bulk material flow on technical and economical performance of a screw conveyor / R.B. Hevko, V.M. Baranovsky, O.L. Lyashuk, B.V. Pohrishchuk, Y.P. Gumeniuk, O.M. Klendii, N.V. Dobizha // INMATEH: Agricultural engineering. - 2018. - Vol. 56. - No. 3. P. $175-184$.

19 Gevko R.B. The investigation of the process of a screw conveyer safety device actuation / R.B. Gevko, O.M. Klendiy // INMATEH: Agricultural Engineering. - 2014. - Vol. 42. - No. 1. - P. 55-60.

С.Ф. Пилипака, Н.Б. Клендий, В.И. Троханяк, А.С. Пастушенко, А.В. Новицкий

\section{Барлық нүктелері көлбеу жазықтықта тербелмелі қозғалыста дөңгелек салатын материалдық бөлшектің қозғалысы}

\footnotetext{
Көлбеу бүртік жазықтық бойымен қозғалған материалдық бөлшектің осы жазықтықта тербелмелі қозғалыста әрбір нүктесі дөңгелек сызатындай қозғалысының дифференциалдық теңдеуі құрылған. Жазықтық бойымен көкжиекке көлбеу бұрышына тәуелді бөлшектің қозғалысының салыстырмалы ерекшеліктері зерттелді. Теңдеулер сандық әдістермен шешілді. Салыстырмалы жылдамдықтар табылды және бөлшектер қозғалысының траекториялары салынды. Жазықтыққа көлбеу бұрышына,
} 
бұрыштық жылдамдыққа, жазықтық бойымен бөлшектің үйкелу коэффициентіне, жазықтық нүктелерінің қозғалысы салған дөңгелек радиусына байланысты бөлшектердің салыстырмалы қозғалысының кинематикалық характеристикалары тағайындалды.

Kiлm сөздер: көлбеу жазықтық, тербелмелі қозғалыс, салыстырмалы қозғалыс, бөлшек, кинематикалық параметрлер.

С.Ф. Пилипака, Н.Б. Клендий, В.И. Троханяк, А.С. Пастушенко, А.В. Новицкий

\title{
Движение материальной частицы по наклонной плоскости, все точки которой в колебательном движении описывают круги в этой же плоскости
}

\begin{abstract}
Составлены дифференциальные уравнения движения материальной частицы по наклонной шероховатой плоскости, осуществляющей колебательное движение таким образом, что каждая ее точка описывает круг в этой же плоскости. Исследованы особенности относительного движения частицы по плоскости в зависимости от ее угла наклона к горизонту. Уравнения решены численными методами. Найдено относительное скорости и построена траектория движения частиц. Установлены кинематические характеристики относительного движения частицы в зависимости от угла наклона плоскости, угловой скорости, коэффициента трения частицы по плоскости и радиуса круга движения точек плоскости.
\end{abstract}

Ключевые слова: наклонная плоскость, колебательное движение, относительное движение, частица, кинематические параметры.

\section{References}

1 Vasilenko P.M. (1960). Teoriia dvizheniia chastitsy po sherokhovatym poverkhnostiam selskokhoziaistvennykh mashin [Theory of particle motion over rough surfaces of agricultural machinery]. Kiev: UASKhN [in Russian].

2 Zaika P.M. (1992). Izbrannye zadachi zemledelcheskoi mekhaniki [Selected tasks of agricultural mechanics]. Kiev: USKhA [in Russian].

3 Pylypaka S.F., Klendii M.B. \& Klendii O.M. (2017). Particle motion over the surface of a rotary vertical axis helicoids. INMATEH: Agricultural engineering, Vol. 51, 1, 15-28.

4 Pylypaka S., Klendii M., Kremets T. \& Klendii O. (2018). Particle motion over the surface of a cylinder, which performs translational oscillations in a vertical plane. Engineering Journal, Vol. 22, 3, 83-92.

5 Hevko R.B., Yazlyuk B.O., Liubin M.V., Tokarchuk O.A., Klendii O.M. \& Pankiv V.R. (2017). Feasibility study of the process of transpotration and stirring of mixture in continuous-flow conveyers. INMATEH: Agricultural engineering, Vol. 51, 1, 49-58.

6 Hevko R.B., Klendii M.B. \& Klendii O.M. (2016). Investigation of a transfer branch of a flexible screw conveyer. INMATEH: Agricultural engineering, Vol. 48, 1, 29-34.

7 Hevko R.B., Rozum R.I. \& Klendii O.M. (2016). Development of design and investigation of operation processes of loading pipes of screw conveyors. INMATEH: Agricultural engineering, Vol. 50, 3, 89-96.

8 Pylypaka S.F., \& Nesvidomin A.V. (2011). Traektory rukhu chastinok po shorstki pokhili ploshchin pri ikh bokovi podachi [Trajectories of particle motion over rough inclined planes at side feed]. Prikladna geometriia ta inzhenerna grafika - Applied Geometry and Engineering Graphics, Vol. 87, 36-41, [in Ukrainian].

9 Blekhman I.I. \& Janelidze G.Yu. Vibratsionnoe peremeshchenie [Vibratory movement]. Moscow: Nauka [in Russian].

10 Pylypaka S., Klendii M. \& Klendii O. (2018). Particle motion on the surface of a concave soil-tilling disk. Acta Polytechnica. Vol. 58, 3, 201-208. 
11 Pylypaka S.F., Klendii M.B., Nesvidomin V.M. \& Trokhaniak V.I. (2019). Particle motion over the edge of an inclined plane that performs axial movement in a vertical limiting cylinder. Acta Polytechnica. Vol. 59, 1, 67-76.

12 Pylypaka S.F., Klendii M.B. \& Trokhaniak V.I. (2019). Particle motion over a plane, which rotates about a horizontal axis and makes a certain angle with it. Bulletin of the Karaganda University. «Mathematics» series. Vol. 93, 1,129-139.

13 Pylypaka S.F., Nesvidomin, V.M., Klendii M.B., Rogovskii I.L., Kresan T.A. \& Trokhaniak V.I. (2019). Conveyance of a particle by a vertical screw, which is limited by a coaxial fixed cylinder. Bulletin of the Karaganda University. «Mathematics» series. Vol. 95, 3, 129-139.

14 Hevko B.M., Hevko R.B., Klendii O.M., Buriak M.V., Dzyadykevych Y.V. \& Rozum R.I. (2018). Improvement of machine safety devices. Acta Polytechnica, Vol.58, 1, 17-25.

15 Hevko R.B., Dzyura V.O. \& Romanovsky R.M. (2014). Mathematical model of the pneumatic-screw conveyor screw mechanism operation. INMATEH: Agricultural engineering, Vol. 44, 3, 103-110.

16 Klendii M.B. \& Klendii O.M. (2016). Interrelation between incidence angle and roll angle of concave disks of soil tillage implements. INMATEH: Agricultural engineering, Vol. 49, 2, 13-20.

17 Romanovsky R.M. Baranovsky V.M., Hevko R.B., Dzyura V.O., Klendii O.M. \& Klendii M.B. (2018). Justification of rational parameters of a pneumoconveyor screw feeder. INMATEH: Agricultural Engineering, Vol. 54, 1, 15-24.

18 Hevko R.B., Baranovsky V.M., Lyashuk O.L., Pohrishchuk B.V., Gumeniuk Y.P., Klendii O.M. \& Dobizha N.V. (2018). The influence of bulk material flow on technical and economical performance of a screw conveyor. INMATEH: Agricultural engineering, vol.56, 3, 175-184.

19 Gevko R.B., \& Klendiy O.M. (2014). The investigation of the process of a screw conveyer safety device actuation. INMATEH: Agricultural Engineering, Vol. 42, 1, 55-60. 